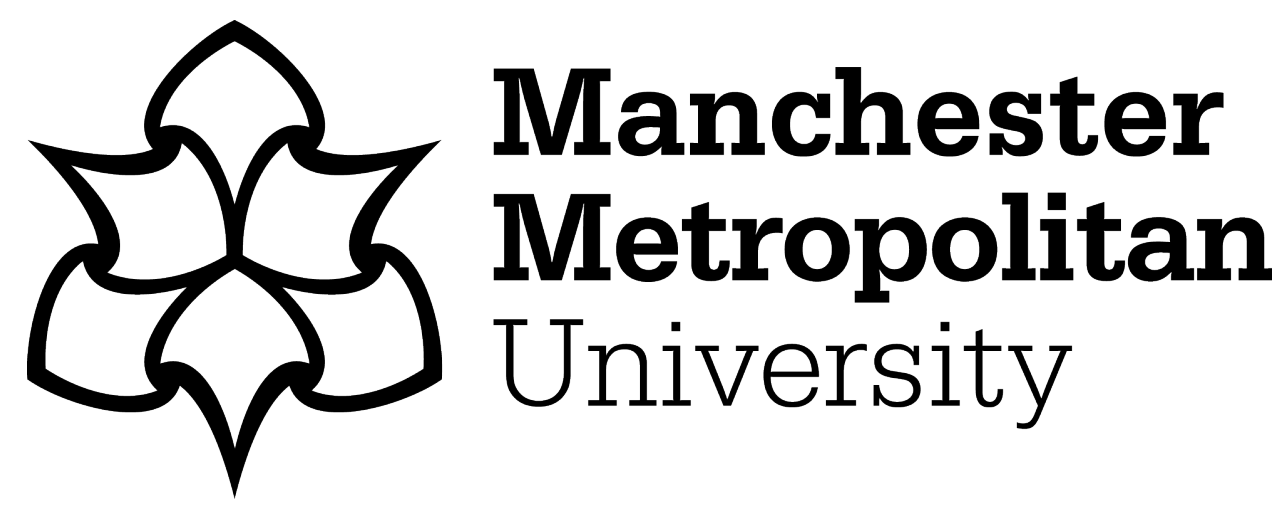

Barnard, MJ ORCID logoORCID: https://orcid.org/0000-0001-6325-5025 (2020) Power and Freedom in Heidegger's First Notebook. Journal of the British Society for Phenomenology, 51 (2). pp. 151-161. ISSN 0007-1773

Downloaded from: https://e-space.mmu.ac.uk/624941/

Version: Accepted Version

Publisher: Taylor \& Francis

DOI: https://doi.org/10.1080/00071773.2019.1690749

Please cite the published version 


\title{
Power and Freedom in Heidegger's First Notebook
}

\author{
Matthew J. Barnard
}

\begin{abstract}
In the first notebook published in Überlegungen II-VI, which covers the years 1931 and 1932, Martin Heidegger uses a conception of power that is different to that found in his later work. Rather than power being the expression of the will to will and source of ruin for humanity, he says that humanity can only be saved from ruin if it can pave the way for an 'empowerment of being' (ermächtigung des Seins). This article will show that this early understanding of power is related to Heidegger's conception of freedom as the essence of truth, developing his thinking on this topic from the period of 1927 to 1930. It will show that the terms 'empowerment of being' and 'letting be' (Seinlassen) are akin, and that Heidegger uses the former to distance his thinking from potential misinterpretations of the essay 'On the Essence of Truth'.
\end{abstract}

\section{Keywords}

Martin Heidegger, Freedom, Truth, Power, Heidegger's Black Notebooks

\section{Article}

The first notebook that is published within Überlegungen $/ I^{1}$ was written between 1931 and 1932. These notes offer a conception of power that does not match the arguments Heidegger makes

${ }^{1}$ This is found in Martin Heidegger, Überlegungen II-VI: (Schwarze Hefte 1931-1938), Martin Heidegger: Gesamtausgabe Bd. 94 (Frankfurt am Main: Klostermann, 2014). Henceforth, GA94, 
about power in the latter half of that decade. Rather than arguing that power is a relentless force that will lead to the ruin of all, in these earlier meditations, Heidegger argues that the cause of nihilistic ruin is, in fact, the lack of an 'empowerment of being' (ermächtigung des Seins). While the notebook does not offer a clear exposition and definition of this early notion of power, I will clarify its nature in the light of the conception of freedom Heidegger developed between 1927 and 1930. Freedom, under this conception, means choosing to be one's being, rather than avoiding this choice. It means letting our being be, rather than fleeing from it. The conception of empowerment of being is an incremental development of this notion: 'to let being be is empower being by way of sustaining it, and thus to let truth happen.' [G94 58-59]

Heidegger typically represents power negatively. In the work of the mid to late 1930s and onward, Heidegger argues that power, properly understood, is will to power, which is to say that the will to the power is the will to will more, to achieve greater mastery and might. As he says in the first volume of his study of Nietzsche,

Willing itself is mastery over..., which reaches out beyond itself; will is intrinsically power. And power is willing that is constant in itself. Will is power; power is will. [...] Because will is resolute openness toward itself, as mastery out beyond itself, because will is a willing beyond itself, it is the strength that is able to bring itself to power. The expression "to power" therefore never means some sort of appendage to the will. Rather, it comprises an elucidation of the essence of will itself. ${ }^{2}$

using marginal pagination, which is also found in the translation: Martin Heidegger, Ponderings Ii-Vi. trans. Richard Rojcewicz (Bloomington: Indianna University Press, 2016).

2 Martin Heidegger, Nietzsche I, Martin Heidegger: Gesamtausgabe Bd. 6.1 (Frankfurt am Main: Klostermann, 1996), pp. 38-39. Martin Heidegger, Nietzsche: Volumes One and Two. trans. David F. Krell (San Francisco: Harper \& Row, 1991), pp. 41-42 
While this is ostensibly his interpretation of Nietzsche's position, as Bret Davis argues, Heidegger's confrontation with Nietzsche 'was also a confrontation with his own embrace of the will.' ${ }^{3}$ In criticising Nietzsche's conception of will, he is investigating the phenomenon of will itself. Out of this, Heidegger concludes that power is the happening of the will. The will is expressed and becomes actual in power. Further, the spread of power is in no way limited to a single set of entities or political factions. As he argues in 'Overcoming Metaphysics':

The struggle between those who are in power and those who want to come to power: On every side there is the struggle for power. Everywhere power itself is what is determinative. Through this struggle for power, the being of power is posited in the being of its unconditional dominance by both sides. At the same time, however, one thing is still covered up here: the fact that this struggle is in the service of power and is willed by it. The will to will alone empowers these struggles. Power, however, overpowers various kinds of humanity in such a way that it expropriates from man the possibility of ever escaping from the oblivion of Being on such paths. ${ }^{4}$ [GA7 89/OM 102]

There can be no doubt of Heidegger's valuation of power at this point: it is a force that dominates the Earth. Power overpowers us to such an extent that we will not be able to escape the oblivion of being. The greater the amount of power the more being forgets us. Further, power is the expression of the will. Machination 'holds it in dominance', which leads to the 'desolation of the earth'. Power, will, and machination also lead to a desolation of the human being: 'It almost seems as if the being of pain were cut off from man under the dominance of the will, similarly the being of joy.' [GA7 110/95]. And, the problem is not that such and such a being is powerful rather than

3 Bret W. Davis, Heidegger and the Will: On the Way to Gelassenheit (Evanston: Northwestern University Press, 2007), p. 147

${ }^{4}$ Martin Heidegger, Vorträge Und Aufsätze, Martin Heidegger: Gesamtausgabe (Frankfurt am Main: Klostermann, 2000), p. 89. Martin Heidegger, The End of Philosophy. trans. Joan Stambaugh (Chicago: The University of Chicago Press, 1973), p. 102. Henceforth, GA7, with original and then translation page numbers. 
another set. As Babette Babich put it, machination 'crosses political borders, as a global essence' 5 . Power itself is undesirable and leads to our ruin.

As such, it is almost incredible to read Heidegger, only a few years before, stating that humanity must learn 'to make Dasein at the same time mature for power and in the of power' [GA94 15]. This early statement contradicts the later and more familiar conception of power. In this later sense, to render Dasein into the service of power would be to secure its ruin. And yet, in the first Black Notebook, we also read that empowerment is the only way to avoid ruin:

What counts is the empowerment of being! And of this alone. And such empowerment is not to be carried out through the presentation of "ontology" or the like, but only through the formative stamping of the essence of being itself.

Can humans do this? They must. Otherwise, they go to ruin on their indifference to Dasein - which means, however, it continues on in that way. [GA94 42]

This conception of power is, then, at odds with Heidegger's later conception. However, Heidegger's usage of the concept in the notebook is hard to decipher. This is symptomatic of the literary form: these are notes, not aphorisms. Heidegger is not trying to teach us what he means by 'empowerment of being', he is using the concept to think through some philosophical problems close to the heart of his project. The notebook has no systematic structure. While themes recur, and, in some places, Heidegger directs us to related notes, there is not enough exposition in the text for us to interpret what 'empowerment of being' means without turning to his other works.

Fortunately, the key thoughts in the notebook that develop into the conception of empowerment offer clues as to where, in Heidegger's works, we need to turn. The notebook begins with the words 'What should we do?' [GA94 1], which is apt. The central motif of the notes is the articulation of what the "task" thinking or philosophy. It becomes clear, as the writing develops, that Heidegger feels that Being and Time failed in that task. In $\S 8$, he describes it as an 'imperfect attempt to enter into the temporality of Dasein in order to answer the question of being for the

\footnotetext{
${ }^{5}$ Babette Babich, 'Heidegger's Will to Power', Journal of the British Society for Phenomenology,
} 38 (2007), 37-60, p. 39 
first time since Parmenides' [GA94 7]. While this statement is a mixed evaluation, since doing anything for the first time since Parmenides has to be regarded as an achievement, only two pages later he criticises the book more deeply. In $\S 13$, Heidegger describes the task by saying 'The essence of truth must first be transformed and must be transposed into a new sharpness and hardness so that beings may find admittance' [GA94 9]. On the basis of this claim, $\S 14$ argues,

Therefore, it was a mistaken view that Being and Time could overcome "ontology" directly. The appalling "result" is indeed only that the prattle about being has increased and has become still more groundless. [GA94 9]

His great treatise, therefore, mistakes the task of 'transforming the essence of truth' for engaging in the academic discipline of ontology. In the next note, we are told that 'Everything is to be set still deeper; thus first made ripe for transformation' [GA94 9]. This theme of articulating a way to dig deeper than Being and Time continues, until it comes to fruition through the usage of the conception of power. In $\S 49$, for example, Heidegger says '[M]y entire literary output [...] has become alien to me' [GA94 20] before, in the note immediately following, he speaks of moving 'out from the foolishness of the idle talk about the situation' towards reflecting on the 'preservation of the power of the origin', which is then clarified with the statement, 'Empowerment as preservation' [GA94 21]. This thought seems to come to maturity in $\S 55$, when Heidegger comes to speak of his commitment to the project of Being and Time, despite the failure of the book:

There is no other option except to write [Being and Time] and only this book again and again. At the risk of remaining a homo unius libri [person of one book]. Beyond this unum [one], there is no aluid [other].

Therefore have to work out the question with more penetration and only just that; not at all the answer. The arrival of its answer at the end something quite peculiar! In working out as semblant analysis the unique valid and lasting empowerment! [GA94 24]

Empowerment is, therefore, something that comes out of Heidegger's critique of Being and Time, but also involves a return to that book. The usage of the concept evokes Heidegger's conceptions of truth and freedom from this period, which is finally confirmed in $\S 124$, when he explicitly places the new concept in comparison to the two more familiar ideas: 


\section{A sketch of the whole:}

The liberation toward Dasein - *6

The empowerment of being-

The truth of the essence.

*The gathering up toward Dasein,

In order to empower being by way of sustaining it

and thus to let truth happen. [G94 58-59]

This 'sketch of the whole' places the empowerment of being as part of key notions of Heidegger's work between 1927 and 1930: those of freedom and the essence of truth (if not truth of essence). While this sketch is not decipherable on its own, it provides sufficient justification to turn to the texts that deal with truth and freedom in order to inform our interpretation. In the next section, I will describe Heidegger's conception of freedom and how it relates to truth, in order to meet this objective.

\section{II}

Philosophers usually speak of freedom in the context of the will and problems of causal determination. The philosophy of freedom, therefore, typically interrogates the possibility of the will's ability to initiate a causal chain and whether this would be a violation of the principle of causation, which states that every effect must have a cause. Heidegger's conception of freedom, however, is premised on a rejection of the suggestion that freedom can be understood in this way. Heidegger is particularly forceful on this point in his 1936 lecture course on Schelling's treatise concerning freedom:

${ }^{6}$ This note was added at a later date. 
The usual discussions about freedom of the will and the attempts to prove its existence or nonexistence all fail in the fundamental error of taking the aforementioned preliminary questions [concerning the phenomenon of freedom, prior to its conceptualisation as a property of the will] too lightly or else not asking them at all. If they were seriously asked, the illusory question about freedom of the will which continually plays havoc in doctrines of morality and law would have long since disappeared, and it would become evident that the real question about freedom is something quite different from what is talked about in "the problem of the freedom of the will."

Heidegger takes the problem of the will to be an 'illusory question' because causal determination is an interpretation of beings, a way in which we investigate and make sense of the world. However, we can only encounter beings as worthy of investigation because Dasein has, as the primary feature of its being, understanding of being. As he puts it in the 1930 lecture course translated as The Essence of Human Freedom, 'Not only does the understanding of being pervade all comportments to beings, in the sense that it is present everywhere, but it is the condition of the possibility of any comportment to any beings whatsoever. ${ }^{8}$ This understanding of being, as the possibility of all comportment, is itself freedom, since it is the ground of all understanding and action. This allowing to be encountered is an act of freedom. As Heidegger puts it in the conclusion of the lecture course:

[T]he understanding of being, has the character of letting-stand-over-against. Letting something stand-over-against as something given, basically the manifestness of beings in the binding character of their so- and that-being, is only possible where the comportment to beings, whether in theoretical or practical knowledge, already acknowledges this binding character. But the latter amounts to an originary self-binding, or, in Kantian terms, the giving of a law unto oneself. The letting-be-encountered of beings, comportment to beings in each and every mode of manifestness, is only possible where freedom exists.

\footnotetext{
${ }^{7}$ Martin Heidegger, Schellings Abhandlung Über Das Wesen Der Menschlichen Freiheit (1809) (Tübingen: Max Niemeyer Verlag, 1971), pp. 18-19. Martin Heidegger, Schelling's Treatise on the Essence of Human Freedom. trans. Joan Stambaugh (Athens, Ohio: Ohio University Press, 1985), pp. 15-16

${ }^{8}$ Martin Heidegger, Vom Wesen Der Menschlichen Freiheit: Einleitung in Die Philosophie, Martin Heidegger: Gesamtausgabe Bd. 31 (Frankfurt am Main: Klostermann, 1994), p. 125. Martin Heidegger, The Essence of Human Freedom. trans. Ted Sadler (London: Continuum, 2005), p. 89. Henceforth, GA31, with original and then translation page numbers.
} 
Freedom is the condition of the possibility of the manifestness of the being of beings, of the understanding of being. [GA31 302/207]

Any encounter with beings presupposes the possibility of encountering them, and the condition of that possibility. Heidegger conceives of freedom as that condition of possibility. Therefore, freedom is required for any encounter or understanding of being. Freedom, then, is not the possibility of an uncaused cause. It is instead what makes possible all possibility. Freedom is here understood in a way close to sentience. It is not a question of a human faculty of choice, but rather of Dasein's ability to encounter being, understand it, and find it to be an issue in the first place. As Heidegger argues in the essay 'The Essence of Ground', published in Wegmarken, 'this understanding of being first makes possible the "why".'9 This claim is not simply negative. In describing freedom as the 'condition of the possibility of the manifestness of the being of beings', Heidegger replaces the 'illusory question' of the freedom of the will with the genuine question of how being is made manifest at all to us.

Developing this line of thought in 'On the Essence of Truth', an essay which, like The Essence of Human Freedom, was written during 1930, Heidegger works out the question of freedom as the manifestness of beings through the concept of truth. He argues that the Greek alettheia be translated as Unverborgenheit: unhiddenness. [WM 188/144]. This is intended to undermine the correspondence theory of truth, which Heidegger refers to as "correctness" (Richtigkeit), and show it as derivative. Heidegger argues this by, first, giving an account of the correspondence theory of truth itself as 'what accords' or 'the consonance of a matter with what is supposed in advance regarding it and, on the other hand, the accordance of what is meant in the statement with the matter.' [WM 179-180/138] In this traditional definition, truth refers to the correspondence of my statement about beings, presupposing the original unconcealment of those beings. Taking the example of 'two five-mark coins lying on the table' [WM 182-183/140], Heidegger argues that we can make truth claims about the coins. We can be incorrect and correct

${ }^{9}$ Martin Heidegger, Wegmarken (Frankfurt, M: Klostermann, 2013), p. 65. Martin Heidegger, Pathmarks (Cambridge: Cambridge University Press, 1967), p. 130. Henceforth, WM with original and then translation page numbers. 
in our judgments about entities, and correctness is justly identified as the adaequatio rei et intellectus. However, the rei are only given in order for us to be correct or incorrect on the basis of a prior revelation of being: only because the world is pregiven to us can beings be encountered. Correctness and incorrectness are, therefore, a 'binding directedness' towards what is pregiven in the unconcealment of the world. Only because the world is given can I be correct or incorrect about it. Going further, Heidegger reverses this insight back upon itself to argue that binding directedness is an act of freedom:

To free oneself for a binding directedness is possible only by being free for what is opened up in an open region. Such being free points to the heretofore uncomprehended essence of freedom. The openness of comportment as the inner condition of the possibility of correctness is grounded in freedom. The essence of truth, as the correctness of a statement, is freedom. [WM 187/142]

As with The Essence of Human Freedom, Heidegger argues that freedom is the ground of our basic encounter with the world. The essay, however, goes further by describing the act of freedom itself: 'Freedom now reveals itself as letting beings be' [WM 188/144]. To be free is to allow beings to be what they are, to allow them to be revealed in their truth, rather than distorting them in the illusion of error. Heidegger develops this insight as follows:

To let be - that is, to let beings be as the beings that they are - means to engage oneself with the open region and its openness into which every being comes to stand, bringing that openness, as it were, along with itself. [WM 188/144]

Freedom, then, is an ontological act. ${ }^{10}$ In freedom, we let the being of beings be unconcealed. This act is the condition of the manifestness of beings. However, it carries with it the possibility of its opposite, which is the unfreedom of not letting beings be:

10 Scholars have raised concerns on this point. Heidegger transitions here between speaking of freedom as a condition of possibility for the understanding of being to speaking of it as an act that can be performed or neglected. It is beyond the scope of this study to enter this debate. However, the reader will find a thorough consideration of the problem in Han-Pile, Béatrice. 2013. 'Freedom and the "Choice to Choose Oneself" in Being and Time.' in Mark A Wrathall (ed.), The Cambridge Companion to Heidegger's 'Being and Time' (Cambridge University Press: Cambridge). 
[B]ecause truth is in essence freedom, historical human beings can, in letting beings be, also not let beings be the beings that they are and as they are. Then beings are covered up and distorted. [WM 191/146]

Freedom, for the Heidegger of 1930, is an ontological act, which is to say an act that reveals the being of beings. This revelation can be truthful, in which case it lets beings be what they are. It can, however, also be errant. If beings are not allowed to be themselves, they are concealed and distorted instead. For this reason, the essence of truth is freedom. Not because ct can make up its own truth, but because the unconcealment of being is not a process in which I am entirely passive. I can let be or not let be, and this is constitutive of truth and error.

III

Heidegger's philosophy of freedom, then, allows for two paths: the path of freedom and truth and the path of unfreedom and error. The act that must be performed to ensure the path of truth is 'letting beings be'. I will show in the next section that the notion of an 'empowerment of being' in the first volume of GA94, is a development of this conception of freedom. However, I first wish to speak briefly about some of the limitations of the conception of freedom given in 'On the Essence of Truth', in order to anticipate why Heidegger would want to move beyond the conception at all. In 'On the Essence of Truth', Heidegger tries to separate himself from the idea of freedom as caprice, or the selection of options by an indifferent will. The first moment he raises this prospect is in the form of a rhetorical question:

To place the essence of truth in freedom - does this mean to submit truth to human caprice? Can truth be any more radically undermined than by being surrendered to the arbitrariness of this "wavering reed"? [WM 187/143]

Here Heidegger raises a common sense interpretation of the claim he is making: humans choose what is true. However, Heidegger makes clear later in the essay that he does not intend freedom to be a property of human beings, but rather the human is possessed by freedom:

[I]f ek-sistent Dasein, which lets beings be, sets the human being free for his "freedom" by first offering to his choice something possible (a being) and by imposing on him something necessary (a being), human caprice does not then have freedom at its 
disposal. The human being does not "possess" freedom as a property. At best, the converse holds: freedom, ek-sistent, disclosive Da-sein, possesses the human being - so originarily that only it secures for humanity that distinctive relatedness to beings as a whole as such which first founds all history. [WM 190/145-146]

The ontological act of letting beings be, therefore, is not a decision made by a human subject. Rather, the human being is only made truly possible by letting beings be. This concern is also expressed in the notebook under discussion:

[Not] the frivolous and non-committal relinquishing of one thing for another according to circumstances. Instead, achievement and empowerment to one decisive attitude that does not remain empty and formal but rather has its decisiveness in making fast and "grounding" the truth of beings in quite determinate horizons of vision and spheres of action. [GA94 26]

When Heidegger speaks about freedom, he does not mean arbitrary choice. However, in doing so, he is in a constant battle with the common meaning of this word. As Charles Guignon put it, Heidegger's use of the word freedom such that it is 'intelligible to say that freedom is the essence of ground and the essence of truth' is, to say the least, 'idiosyncratic'. ${ }^{11}$ The term 'empowerment', however, in its ordinary usage, indicates something closer, though still not identical, with what Heidegger wants to say. If we empower someone or something, we enable them to determine our way of being, at least to some extent. The empowerment of a democratic government by its citizens determines their lives, for example. An empowerment of being would be choice to let our being determine how we are, rather than some other way of being. This is, of course, one of the central problematics of Being and Time: the question of authenticity or Dasein's possibility of being-its-self. Most poignantly, Heidegger describes Dasein's lostness in the they with an image closer to power than to freedom, that of a 'dictatorship of the they':

In utilizing public means of transport and in making use of information services such as the newspaper, every other is like the next. This Being-with-one-another dissolves one's own Dasein completely into the kind of Being of 'the Others', in such a way, indeed, that the Others, as distinguishable and explicit, vanish more and more. In this

${ }^{11}$ Charles Guignon, 'Heidegger's Concept of Freedom, 1927-1930', in Interpreting Heidegger, ed. by Daniel O Dahlstrom (Cambridge: Cambridge University Press, 2011), pp. 79-105, p. 80 
inconspicuousness and unascertainability, the real dictatorship of the "they" is unfolded. We take pleasure and enjoy ourselves as they take pleasure; we read, see, and judge about literature and art as they see and judge; likewise we shrink back from the 'great mass' as they shrink back; we find 'shocking' what they find shocking. The "they", which is nothing definite, and which we all are, though not as the sum, prescribes the kind of Being of everydayness. ${ }^{12}$

Dasein's inauthenticity is most visible in its conforming to the everyday, which could, importing the ideas within the 1931 notebook, be described as a disempowerment of being. In using public transport, Dasein's ownmost possibility is not at work; instead, Dasein is disburdened of this possibility. Empowerment, in the first Black Notebook, allows Heidegger to distinguish more strongly the idea he is advocating from these twin poles of individual caprice and conformist anonymity. Just as Being and Time does not present authenticity as a form of "individualism" as opposed to a naïve "conformism", the empowerment of being is described in opposition to both the individual and the community. Heidegger writes that the desired 'empowerment' is 'nothing an individual is capable of' but also 'nothing appropriated by a community' [GA94 48]. It is not a matter of empowering individuals or communities, but rather empowering being, which for us as humans means our Dasein.

We can see the transition from freedom to empowerment most clearly in note $\S 36$. Here, Heidegger asks the question 'Can an individual still compel something essential? Does that not lack the community of the few who enjoy it?' These questions operate in the context of Heidegger's problem of freedom. The address the issue of how we can let beings be, although the expression is inadequate, as Heidegger himself quickly states: 'Yet, are these not questions stemming from a merely semblant thoughtfulness?' The closeness to the conception of freedom and 'On the Essence of Truth' is reinforced by the immediately following lines:

Must not a responsibility simply be accepted?

12 Martin Heidegger, Sein und Zeit (Tübingen: Max Niemeyer Verlag, 2006), pp. 126-127. Martin Heidegger, Being and Time. trans. John Maquarrie and Edward Robinson (Oxford: Blackwell, 1967), H. 126-127. Henceforth, SZ followed by the original page numbers, which are found in the margins of the translation. 
What is a responsibility?

To pledge oneself for something and sacrifice oneself!

Pledge oneself to what? For Da-sein to become powerful in humans and their measure and might! [GA94 16]

In this passage, Heidegger briefly considers the notion of responsibility as a more profound way into the problem of letting the essential arise. While the terms used here are not the same as those in 'On the Essence of Truth', there is a strong resonance. The idea of pledging oneself recalls the 'binding directedness' [WM 187/142] of correctness. Further, as with the essay, this responsibility is better clarified by bringing Dasein to prominence. Where the essay says that 'disclosive Da-sein, possesses the human being - so originarily that only it secures for humanity that distinctive relatedness to beings as a whole as such which first founds all history' [WM 190/145-146], the note tells us that Heidegger true responsibility is to pledge for Dasein to become powerful in humanity. And so, Heidegger has introduced the concept of empowerment, and its implied opposite, disempowerment, to think beyond the linguistic possibilities afforded by the word 'freedom' and 'truth'.

\begin{abstract}
IV
The concept of power in the first Black Notebook and Heidegger's conceptions of freedom and truth, therefore, are akin. The notebooks use the idea of power to push the thought further away from the poles of individual caprice and conformism. However, empowerment does not replace the conception of freedom. Rather, it complements it. This will become clear if we return to $\S 124$, which I last discussed at the end of Section II of this essay. There, Heidegger gives us what he calls 'a sketch of the whole'. In it, he links the concepts of freedom, empowerment, and truth together:
\end{abstract}

A sketch of the whole:

The liberation toward Dasein - *

The empowerment of being-

The truth of the essence. 
*The gathering up toward Dasein,

In order to empower being by way of sustaining it and thus to let truth happen. [G94 58-59]

In the annotation, Heidegger clarifies liberation as something that makes the empowerment of being possible, which in turn allows the truth to happen. And, if freedom is the essence of truth, then the phrase 'to let truth happen' (Wahrheit geschehen lassen) is synonymous with 'letting be' (Seinlassen). This clue suggests we should read the original list as a statement of three moments in a unitary phenomenon, rather than a hierarchy. The sketch is truly of a whole.

In introducing 'empowerment of being', however, Heidegger is able to think beyond what he argued in 'On the Essence of Truth'. As consistent as Heidegger is in telling us that freedom 'does not signify a free-floating potentiality-for-Being in the sense of the "liberty of indifference"' [SZ 144], his usage of the term that makes it the essence of truth will always raise the question, 'Can truth be any more radically undermined than by being surrendered to the arbitrariness of this "wavering reed?"' [WM 187/143] This early conception of power complements his discourse on freedom and truth. To let be does not mean an act of will that permits beings to be what they are, it means allowing being to empower beings, in contrast to avoiding and suppressing that power. As such, not only is Heidegger's earlier concept of power different to the later, it is its opposite.

\section{Bibliography}

Babette Babich, 'Heidegger's Will to Power', Journal of the British Society for Phenomenology, 38 (2007), 37-60.

Steven Crowell, 'Reading Heidegger's Black Notebooks', in Reading Heidegger's Black Notebooks 1931-1941, ed. by Ingo Farin and Jeff Malpas (Cambridge: The MIT Press, 2016), pp. 29-44.

Fred Dallmayr, 'Heidegger on Macht and Machenschaft', Continental Philosophy Review, 34 (2001), 247-67. 
- - , 'Heidegger's Notebooks: A Smoking Gun?', in Reading Heidegger's Black Notebooks 19311941, ed. by Ingo Farin and Jeff Malpas (Cambridge: The MIT Press, 2016), pp. 23-28.

Bret W. Davis, Heidegger and the Will: On the Way to Gelassenheit (Evanston: Northwestern University Press, 2007).

Günter Figal, Martin Heidegger: Phänomenologie Der Freiheit (Tübingen: Mohr Siebeck, 2013), p. 400.

Jean Grondin, 'The Critique and Rethinking of Being and Time in the First Black Notebooks', in Reading Heidegger's Black Notebooks 1931-1941, ed. by Ingo Farin and Jeff Malpas (Cambridge: The MIT Press, 2016), pp. 95-108.

Charles Guignon, 'Heidegger's Concept of Freedom, 1927-1930', in Interpreting Heidegger, ed. by Daniel O Dahlstrom (Cambridge: Cambridge University Press, 2011), pp. 79-105.

Michel Haar, 'The Question of Human Freedom in the Later Heidegger', The Southern Journal of Philosophy, 28 (1990), 1-16.

Béatrice Han-Pile, 'Freedom and the "Choice to Choose Oneself" in Being and Time', in The Cambridge Companion to Heidegger's 'Being and Time', ed. by Mark A Wrathall (Cambridge: Cambridge University Press, 2013), pp. 291-319.

Martin Heidegger, Being and Time. trans. John Maquarrie and Edward Robinson (Oxford: Blackwell, 1967).

- - , The End of Philosophy. trans. Joan Stambaugh (Chicago: The University of Chicago Press, 1973).

- - , The Essence of Human Freedom. trans. Ted Sadler (London: Continuum, 2005).

- - , Nietzsche I, Martin Heidegger: Gesamtausgabe (Frankfurt am Main: Klostermann, 1996).

- - , Nietzsche: Volumes One and Two. trans. David F. Krell (San Francisco: Harper \& Row, 1991).

- - , Pathmarks (Cambridge: Cambridge University Press, 1967). 
- - , Schellings Abhandlung Über Das Wesen Der Menschlichen Freiheit (1809) (Tübingen: Max Niemeyer Verlag, 1971).

- - - Schelling's Treatise on the Essence of Human Freedom. trans. Joan Stambaugh (Athens, Ohio: Ohio University Press, 1985).

- - - Sein Und Zeit (Tübingen: Max Niemeyer Verlag, 2006).

- - , Überlegungen II-IV: (Schwarze Hefte 1931-1938), Martin Heidegger: Gesamtausgabe Bd. 94 (Frankfurt am Main: Klostermann, 2014).

- - - Vom Wesen Der Menschlichen Freiheit: Einleitung in Die Philosophie, Martin Heidegger: Gesamtausgabe Bd. 31 (Frankfurt am Main: Klostermann, 1994), p. 307.

- - - Vorträge Und Aufsätze, Martin Heidegger: Gesamtausgabe Bd. 7 (Frankfurt am Main: Klostermann, 2000).

- - Wegmarken (Frankfurt, M: Klostermann, 2013).

Friedrich-Wilhelm von Herrmann, 'The Role of Martin Heidegger's Notebooks within the Context of His Oeuvre', in Reading Heidegger's Black Notebooks 1931-1941, ed. by Ingo Farin and Jeff Malpas (Cambridge: The MIT Press, 2016), pp. 89-94.

François Jaran, 'Toward a Metaphysical Freedom: Heidegger's Project of a Metaphysics of Dasein', International Journal of Philosophical Studies, 18 (2010), 205-27.

Jeff Malpas, 'On the Philosophical Reading of Heidegger: Situating the Black Notebooks', in Reading Heidegger's Black Notebooks 1931-1941, ed. by Ingo Farin and Jeff Malpas (Cambridge: The MIT Press, 2016), pp. 3-22.

Hans Ruin, 'The Destiny of Freedom: In Heidegger', Continental Philosophy Review, 41 (2008), 27799.

Stefan W. Schmidt, Grund Und Freiheit: Eine Phänomenologische Untersuchung Des Freiheitsbegriffs Heideggers, Phaenomenologica (Cham: Springer, 2016), p. 226. 
Reiner Schürmann, Heidegger on Being and Acting: From Principles to Anarchy. trans. ChristineMarie Gros (Bloomington: Indiana University Press, 1990), p. 406.

Daniela Vallega-Neu, 'The Black Notebooks and Heidegger's Writings on the Event (1936-1942)', in Reading Heidegger's Black Notebooks 1931-1941, ed. by Ingo Farin and Jeff Malpas (Cambridge: The MIT Press, 2016), pp. 127-42.

Nancy A. Weston, 'Thinking the Oblivion of Thinking: The Unfolding of Machenschaft and Rechnung in the Time of the Black Notebooks', in Reading Heidegger's Black Notebooks 1931-1941, ed. by Ingo Farin and Jeff Malpas (Cambridge: The MIT Press, 2016), pp. 127-42. 